\title{
KOLABORASI PENULIS DALAM BERITA BIOLOGI JURNAL ILMU-ILMU HAYATI 2011-2016
}

\author{
Rochani Nani Rahayu*
}

Pengutipan: Rahayu, R. N. (2017). Kolaborasi penulis dalam Berita Biologi Jurnal Ilmu-ilmu Hayati 2011-2016. Khizanah al-Hikmah : Jurnal Ilmu Perpustakaan, Informasi, dan Kearsipan. (5)2, 196206.

DOI: https:/ / doi.org/10.24252/kah.v5i2a7

\section{*Pustakawan Universitas Pelita Harapan \\ imanhery@gmail.com}

\begin{abstract}
ABSTRAK
Berita Biologi Jurnal Ilmu-ilmu Hayati merupakan salah satu terbitan berkala di Indonesia yang fokus pada bidang biologi. Terbit sejak 16 tahun lalu belum ada kajian yang mengupas tentang kolaborasi penulis dalam artikel yang dimuat di dalamnya. Oleh karena itu dilakukan penelitian deskriptif terhadap artikel yang dimuat dalam terbitan tersebut sejak 2011-2016, dengan tujuan untuk mengetahui 1) Jumlah artikel yang dimuat di dalamya, 2) Jumlah referensi yang digunakan dalam artikel tersebut, 3) Jumlah dan jenis kelamin penulis serta 4) Kolaborasi penulis. Hasil penelitian menunjukkan bahwa : 1) Artikel yang dimuat berjumlah 241 judul, 2) Jumlah referensi yang digunakan adalah 21,48 judul/artikel, 3) Jumlah penulis 611 orang terdiri atas laki-laki 319 orang $(52,21 \%)$ dan perempuan 291 orang $(47,79 \%)$; 4) Nilai tingkat kolaborasi penulis rata-rata sebesar 0,78 dan Ani Susilawati merupakan penulis produktif dengan jumlah artikel 5 judul berasal dari Balai Penelitian Pertanian Lahan Rawa (BALITTRA) Kementerin Pertanian. Disimpulkan bahwa dari 241 judul artikel, penulis laki-laki lebih dominan dibandingkan penulis perempuan, penulis berkolaborasi lebih banyak dibandingkan dengan penulis individu, dan diketahui penulis paling produktif adalah perempuan berasal dari luar LIPI.
\end{abstract}

Kata Kunci: Biologi, jurnal, kolaborasi penulis, artikel

\section{ABSTRACT}

Berita Biologi Jurnal Ilmu-ilmu Hayati is the one of serial in biological field in Indonesia. Published since sixteen years ago no one studied about the author collaboration from this journal, therefore the descriptive method analysis conduct to this publication. The study aims to know: 1) A total of articles publish in this jurnals peride 2011-2016; 2) References used in these journal articles; 3) How many author and their sexs; 4) Author collaboration. Research results were; 1) A total of articles published in this journal were 241 titles; 2) References used by these articles were 21,48 title/article; 3) A total of 611 author consist of 319 men (52,21\%) and 291 women $(47,79 \%)$; 4) The means of degree of author collaboration was 0,78. Ani Susilawati was the most productive author with five articles and she came from Center for Agricultural of Swamp Land. It was conluded that from a total of 241 articles, men more dominant in writing than women, mostly articles wrote by collaboration than by individual. The most productive author was woman and she came not from LIPI.

Keywords : Biology, journals, author collaboration, articles 


\section{PENDAHULUAN}

\section{a. Latar Belakang}

Biologi merupakan suatu bidang ilmu yang pengetahuan alam bersifat mendasar dan sangat diperlukan di Indonesia yang merupakan negara yang kaya akan sumber daya hayati. Oleh karena itu, selaku negara agraris, Indonesia sangat memerlukan perkembangan terbaru di bidang ilmu biologi dan turunannya. Salah satu sumber informasi dalam ilmu biologi adalah Berita Biologi Jurnal Ilmuilmu Hayati, yaitu salah jurnal ilmiah terbitan Pusat Penelitian Biologi Lembaga Ilmu Pengetahuan Indonesia (LIPI), dengan alamat Pusat Penelitian Biologi LIPI, Kompleks Cibinong Science Center J1. Raya Jakarta-Bogor Km 46, Cibinong 16911 Bogor.

Berita Biologi Jurnal Ilmu-ilmu Hayati merupakan terbitan berseri yang sudah terbit hingga volume 16 pada tahun 2017, dan sudah mendapatkan akreditasi berturut-turut sejak 2009 dengan nomor Surat Keputusan Kepala LIPI Nomor 180/AUI/P2MBI/08/2009, diperbarui pada 2012 dengan SK Kepala LIPI Nomor 436/AU2/P2MI-LIPI/08/2012 dan berikutnya adalah SK Kepala LIPI Nomor 636/AU3/P2M-LIPI/07/2015.

Berita Biologi diterbitkan sebanyak tiga kali dalam setahun yaitu bulan April, Agustus dan Desember.

Adapun tujuan diterbitkannya Berita Biologi adalah sebagai media komunikasi guna meningkatkan pengetahuan diantara para peneliti, ilmuwan, para pengambil kebijakan serta pelaku dan pemerhati di bidang biologi. Berita Biologi mempunyai nomor ISSN 0216-91754. Adapun Berita Biologi berisikan berbagai turunan ilmu biologi dengan konsentrasi pada bidang Mikrobiologi, Mikologi, Genetika, Taksonomi, Biologi Molekuler,
Bioteknologi, Veteriner, Biologi peternakan, Ekologi, Biokimia, Fisiologi, Biostatistik, Biologi Tanah, Biodiversitas dan Iklim, dan Biologi Kelautan.

Selama hampir 16 tahun sejak diterbitkannya Berita Biologi tentu sudah banyak hasil penelitian yang berhasil disebarluaskan kepada masyarakat pengguna. Hasil penelitian yang dihasilkan tersebut merupakan salah satu keluaran dari Pusat Penelitian Biologi Lembaga Ilmu Pengetahuan Indonesia dan guna mendapatkan gambaran secara rinci tentang isi dari Berita Biologi diperlukan suatu analisis dari publikasi tersebut.

\section{b. Manfaat Penelitian}

Hasil penelitian dapat digunakan digunakan sebagai masukan kepada pengambil kebijakan penelitian baik pimpinan lembaga penelitian maupun Kementerian Riset dan Teknologi dan Pendidikan Tinggi untuk mengetahui kontribusi para ilmuwan di bidang biologi.

\section{c. Rumusan Masalah}

Permasalahan yang menjadi dasar penelitian adalah:

1) Berapa jumlah artikel yang dimuat dalam Berita Biologi Jurnal Ilmu-ilmu Hayati?

2) Berapa jumlah referensi yang digunakan dalam artikel Berita Biologi Jurnal Ilmu-ilmu Hayati?

3) Berapa jumlah dan jenis kelamin penulis artikel Berita Biologi Jurnal Ilmu-ilmu Hayati?

4) Bagaimana tingkat kolaborasi dan produktivitas penulis artikel Berita Biologi Jurnal Ilmu -ilmu Hayati? 


\section{d. Ruang Lingkup dan Cakupan Penelitian}

Ruang lingkup penelitian meliputi seluruh terbitan Berita Biologi Jurnal Ilmu-ilmu Hayati periode 2011-2016.

\section{KAJIAN PUSTAKA}

\section{a. Kolaborasi Penelitian}

Selepas beberapa tahun belakangan terjadi peningkatan di antara para peneliti/penulis serta para pengambil kebijakan iptek (science policy) yang tertarik dengan penelitian yang dilakukan secara berkolaborasi. Telah banyak dilakukan inisiatif yang bertujuan untuk mengembangkan kolaborasi penelitian di antara para penulis/peneliti yang pada awalanya bekerja sendiri-sendiri.

Diajak untuk melakukan penelitian seara bersama. Secara intens pemerintah berperan untuk meningkatkan kolaborasi penelitian dari yang tingkatannya nasional ke internasional. (Katz, J.S and Martin, BR, 1997).

Secara tersirat antusiasme dalam kolaborasi penelitian dan kebijakan bertujuan untuk pembinaan bagi peneliti. Hal ini akan mudah dicapai apabila konsep dari kolaborasi penelitian sudah diketahui dengan baik. Penting juga diperhatikan apakah kolaborasi yang akan dilakukan berpatokan kepada kolaborasi antar individu peneliti, kelompok, institusi, antar sektor atau antar negara. Seiring berjalannya waktu mulai terlihat bahwa penelitian yang dilakukan secara kolaborasi semakin banyak. Namun Hagstrom (1965) dalam Katzt, J.S dan martin, BR, 1977, menemukan bahwa dalam beberapa publikasi dijumpai daftar penulis hanya karena alasan sosial semata. Walaupun asesmen kolaborasi menggunakan kepengarangan kurang sempurna, namun tetap berguna karena bersifat invariant dan dapat diverifikasi , serta memberikan akses yang sama pada suatu set data, relatif tidak mahal serta metode yang digunakan sederhana walaupun data yang diolah cukup besar.

Beberpa faktor yang berpengaruh terhadap terjadinya kolaborasi penelitian antara lain adalah adanya pertukaran atau sharing data, peneliti mengerjakan projek masing- masing selanjutnya projek-projek tersebut digabungkan menjadi satu kesatuan penelitian. Posisi peneliti dalam suatu kolaborasi penelitian juga dapat berubah tergantung kepada kontribusi pendanaan setiap peneliti. Faktor lain adalah adanya disiplin ilmu yang semakin banyak dan mendalam, sehingga paneliti memperoleh pengalaman untuk melakukan penelitian lintas disiplin. Adanya kebutuhan dari peneliti untuk bekerja secara lebih dekat secara fisik dalam rangka mendapatkan tacit knowledge serta kemampuan dari setiap anggota penlitian. Kolaborasi penelitian lebih banyak terjadi pada jenis penelitian ekperimental yang menggunakan berbagai peralatan instrumentasi yang canggih -canggih misalnya CT scanner, teleskop, (Katz, J.S and Martin, BR, 1997).

Conversely, dkk dalam Katz, J.S and Martin, BR, 1997, mengatakan bahwa kepengarangan merefleksikan kerjasama timbal balik pengaruh intelektual dan pengaruh sosial.Walaupun pada awalnya sebagian besar kolaborasi penelitian dari adanya komunikasi informal dan selanjutnya diteruskan dengan adanya komitmen untuk bekerjasama. Kolaborasi seringkali terjadi antara murid dan guru, bahkan walaupun bukan merupakan kolaborasi secara formal biasanya para guru tetap melakukan supervisi atas murid-muridnya, dan ikatan itu bisa berlanjut hingga bertahun-tahun. Di 
samping itu, kolaborasi juga dapat terjadi dalam berbagai tingkatan seperti antar bagian dalam satu institusi, antar lembaga penelitian, juga antar negara.

Menurut Gordon (1980), tingkat kompetensi yang dimiliki oleh beberapa anggota peneliti memberikan nilai tambah sehingga kualitas penelitian yang dihasilkan menjadi lebih baik. Semakin banyak penulis yang terlibat dalam sebuah artikel berpengaruh secara positif terahadap impact factor secara proporsional, sehingga semakin banyak penulis maka impact factor dari tulisan semakin tinggi yang ditunjukkan dengan semakin banyaknya sitiran dari artikel tersebut.

\section{b. Kolaborasi Peneliti di Bidang Biologi}

Ilustrasi tentang kolaborasi penelitian di bidang biologi antara lain adalah sebagai berikut. Hasil studi Neelamma, et al (2016) menunjukkan bahwa dari 1.183 literatur bidang botani selama 2005-2014 nilai tingkat kolaborasi adalah 0,617 dengan indeks kolaborasi sebesar 0,005, rata-rata jumlah penulis per judul artikel adalah 2,585. Adapun Inggris dan Amerika Serikat merupakan negara penghasil artikel bidang botani paling aktif.

Menggunakan metode bibliometrika dilakukan analisis terhadap database tentang biokimia dan biologi molekuler periode 1999-2002, yang diambil dari Science Citation Index (SCI) dengan hasil sebagai berikut. Hampir separo dari publikasi dimuat di jurnal Cina di luar Hong Kong, Macao dan Taiwan, berasal dari Chinese Academy of Sciences $(39,76 \%)$ disusul National Universites $(38,37 \%)$ dan General Universities $(13,43 \%)$, dan sisanya berasal dari $>6$ instansi/lembaga riset. Sebanyak $79 \%$ artiel ditulis dalambahasa Cina dan 21\% ditulis dalam bahasa Inggris. Penelitian dilakukan mandiri tanpa kolaborasi sebanyak 61,24\%, selanjutnya penelitian dilakukan secara nasional sebanyak $28,76 \%$ dan kolaborasi internasional berjumlah 10 \% (T. He, et al; 2005).

Artikel yang dipublikasikan dari Departemen Zoologi Universitas Burdwan, India sebanyak 251 judul dan 189 judul artikel dari Departemen Botani selama 1976-1980 setelah dianalisis tentang derajat kolaborasi diketahui nilai untuk artikel bidang botani adalah 0,70 dan bidang zoologi adalah 0,51 ( Amitaya N. and Amit, K.B; 2012).

Suatu analisis bibliometrika yang dilakukan oleh Chanda A. and Superna, S. pada 2011 pada bidang veteriner di India yang diambil dari pangkalan data CABI Abstract periode 2006-2010; menunjukkan bahwa derajad kolaborasi rata-rata diperoleh sebesar 0,84 yang menandakan bahwa penelitian berkolaborasi lebih banyak dilakukan dibandingkan penelitian mandiri.

Narendra, K (1986) melakukan studi terhadap 132 artikel pada Journal of Environmental Biology 1980-1984 tentang patron kepengarangan dengan hasil sebagai berikut. Sebanyak 14 judul artikel $(10,61 \%)$ adalah pengarang tunggal adapun 118 judul (89,39\%) merupakan artikel yang ditulis secara kolaborasi berdua dan bertiga. Artikel terbanyak berasal dari perguruan tinggi dan lembaga riset.

Vimala, V and Reddy P.V (1996), melakukan studi terhadap 19.323 judul jurnal yang disitir dalam tesis doktoral bidang zoologi dari Universitas Sri Venkateswara, Tirupati India, periode 1901 - 1995 menunjukkan bahwa penulis berkolaborasi lebih banyak dibandingkan 
dengan penulis tunggal. Pengarangganda dijumpai sebanyak $74,85 \%$, dan proporsi dari pengarang tunggal menunjukkan tendensi penurunan dari $100 \%$ pada 1901 1905 menjadi 5,26\% selama 1991-1995. Jumlah peneliti per judul artikel meningkat dari 1,00 pada kurun 1901-1905 menjadi 3.03 selama 1991-1995.

Kotti, T. (2017), melakukan analisis bibliometrik terhadap 2.052 artikel dari Journal of Crustacean Biology periode 1981-2009, menunjukkan bahwa terjadi kenaikan jumlah artikel untuk periode 1981-1993 dari 50 ke 93 selanjutnya menurun kembali pada 2002 menjadi 70 judul. Rata- rata penulis dan referensi per artikel adalah 1,87 dan 2, 20 dengan jumlah halaman rata-rata per artikel adalah 11 halaman.

Thanuskodi, S. (2012) menyatakan bahwa dari penelitian yang dilakukan terhadap 602 artikel Indian Journal of Agricultural Research ditemukan bahwa 564 judul artikel $(93,69 \%)$ ditulis secara kolaborasi dan sisanya 38 judul $(6,31 \%)$ ditulis secara individual. Adapun pola kepengarangan dapat diterangkan sebagai berikut. Jumlah artikel yang ditulis secara individu 38 judul (6,31\%), artikel yang ditulis oleh dua orang berjumlah 21 judul $(35,71 \%)$, berikutnya untuk artikel yang ditulis oleh tiga penulis berjumlah 189 artikel $(31,39 \%)$, artikel yang ditulis oleh empat penulis sebanyak $113(18,78 \%)$ dan artikel yang ditulis oleh > lima orang berjumlah 47 judul (7,81\%). (Sebanyak $98,67 \%$ artikel ditulis oleh penulis India dan sisanya oleh penulis dari negara lain.

Dhiman A.K. (2000), menemukan dari hasil penelitian yang dilakukan terhadap Ethnobotany Journal periode 1969-1998 bahwa pola kepengarangan digambarkan sebagai berikut. Jumlah penulis tunggal atau artikel yang ditulis secara mandiri berjumlah 69 judul $(29,60 \%)$, berikutnya artikel yang ditulis oleh dua pengarang sebanyak 61 judul $(35,50 \%)$, artikel yang diulis secara kolaborasi tiga orang sebanyak 31 judul $(17,80 \%)$ dan sebanyak 13 judul ( 7,50\%) artikel ditulis oleh lebih dari tiga orang.

\section{METODOLOGI PENELITIAN}

\section{a. Metode Penelitian}

Dalam penelitian ini digunakan metode bersifat deskriptif yaitu suatu metode untuk memberikan gambaran terhadap objek penelitian melalui data yang dikumpulkan apa adanya tanpa intervensi atau perlakuan dari luar sehingga hasil yang didapatkan juga bersifat objektif.

\section{b. Populasi dan Sampel}

Populasi dan sampel yang digunakan adalah seluruh artikel yang dimuat dalam terbitan sekaligus merupakan sumber data digunakan terbitan Berita Biologi Jurnal Ilmu- ilmu Hayati yang diterbitkan oleh Pusat Penelitian Biologi periode 20112016, dalam bentuk tercetak.

\section{c. Instrumen Penelitian}

Instrumen penelitian adalah variabel yang ingin diketahui dalam pertanyaan penelitian yaitu jumlah artikel, jumlah referensi yang digunakan dalam artikel, jumlah dan jenis kelamin penulis.

\section{d. Teknik Pengumpulan Data}

Data dikumpulkan dengan jalan mengunduh dari sumber data kemudian dicatat ke dalam lembar kerja yang ditentukan sebagai berikut. 
Tabel 1. Worksheet pengumpulan data

Berita Biologi Jurnal Ilmu-ilmu Hayati 2011-2016

\begin{tabular}{|l|l|l|l|l|l|l|l|l|l|}
\hline Judul & Penulis & Tahun & $\begin{array}{c}\text { Jumlah } \\
\text { referensi }\end{array}$ & $\begin{array}{c}\text { Laki- } \\
\text { laki }\end{array}$ & Perempuan & $\mathbf{1}$ & $\mathbf{2}$ & $\mathbf{3}$ & $>3$ \\
\hline & & & & & & & & & \\
\hline & & & & & & & & & \\
\hline
\end{tabular}

\section{e. Teknik Analisis Data}

Data yang diperoleh selanjutnya dikelompokan ke dalam kategori yaitu: jumlah artikel, jumlah referensi, jumlah dan jenis kelamin penulis.

Data dihitung menggunakan rumus:

$$
\begin{aligned}
& P=\mathbf{f} / \mathbf{N x} \mathbf{1 0 0} \% \\
& P \quad=\text { persentase } \\
& F \quad=\text { frekuensi } \\
& N=\text { jumlah total (artikel/referensi/ } \\
& \text { jenis kelamin) }
\end{aligned}
$$

Hasil yang diperoleh kemudian disajikan dalam bentuk tabel dan selanjutnya dilakukan penarikan kesimpulan.

Adapun pengolahan data yang digunakan untuk menghitung tingkat kolaborasi penulis dilakukan menggunakan rumus dari Subramanyam (1983) yaitu:

\section{$\mathrm{C}=\mathrm{Nm} / \mathrm{Nm}+\mathrm{Ns}$}

C : adalah tingkat kolaborasi peneliti dalam sebuah disiplin ilmu, nilai $C$ tersebut berada pada interval nol sampai satu, (0 -1).

$\mathrm{Nm}$ : adalah total hasil penelitian dari penulis dalam sebuah disiplin ilmu pada tahun tertentu yang dilakukan secara berkolaborasi.
Ns : adalah total hasil penelitian dari penulis dalam sebuah disiplin ilmu pada tahun tertentu yang dilakukan secara individual (Subramanyam, 1983).

\section{HASIL PENELITIAN DAN PEMBAHASAN}

\section{a. Jumlah Artikel Berita Biologi Jurnal Ilmu-ilmu Hayati 2011-2016}

Berdasarkan Tabel 2 dapat diketahui bahwa jumlah artikel dari 2011-2016 adalah 241 judul, dengan perincian sebagai berikut. Artikel pada 2011 sampai dengan 2016 berturut-turut adalah 48 judul (19,91\%), 44 judul (18,26\%), 45 judul $(18,67 \%), 38$ judul $(15,76 \%), 32$ judul $(13,28 \%)$ dan 34 judul $(14,11 \%)$.

Tabel 2. Jumlah artikel Berita Biologi 20112016

\begin{tabular}{|c|c|c|}
\hline Tahun & Artikel & Persentase $(\%)$ \\
\hline 2011 & 48 & 19,91 \\
\hline 2012 & 44 & 18,26 \\
\hline 2013 & 45 & 18,67 \\
\hline 2014 & 38 & 15,76 \\
\hline 2015 & 32 & 13,28 \\
\hline 2016 & 34 & 14,11 \\
\hline Jumlah & 241 & 100 \\
\hline
\end{tabular}

Terlihat kecenderungan jumlah artikel yang dimuat dalam Berita Biologi semakin muda tahun terbit jurnal, jumlah artikel yang dimuat semakin menurun. Hal tersebut diduga salah satunya diakibatkan oleh berkurangnya anggaran penelitian yang diterima oleh Lembaga Ilmu Pengetahuan Indonesia khususnya Pusat Penelitian Biologi sehingga berakibat turunnya jumlah penelitian yang dilakukan oleh Pusat Penelitian Biologi. 


\section{b. Jumlah Referensi dalam Artikel Berita Biologi Jurnal Ilmu-ilmu Hayati 2011-2016}

Jumlah rerefensi yang digunakan Berita Biologi selama 2011-2016 adalah 5.178 judul adapun jumlah artikel yang terbit sebanyak 241 judul sehingga ratarata jumlah referensi adalah 21,48 judul/artikel.

Tabel 3. Jumlah referensi per artikel tahun 2011-2016

\begin{tabular}{|c|c|c|l|}
\hline Tahun & $\begin{array}{l}\text { Jumlah } \\
\text { artikel }\end{array}$ & $\begin{array}{l}\text { Jumlah } \\
\text { referensi } \\
\text { (judul) }\end{array}$ & $\begin{array}{l}\text { Referensi/ } \\
\text { artikel: }\end{array}$ \\
\hline 2011 & 48 & 991 & $20,64 \mathrm{jdl} /$ art \\
\hline 2012 & 44 & 907 & $20,61 \mathrm{jdl} /$ art \\
\hline 2013 & 45 & 977 & $21,71 \mathrm{jdl} /$ art \\
\hline 2014 & 38 & 825 & $21,71 \mathrm{jdl} /$ art \\
\hline 2015 & 32 & 733 & $22,91 \mathrm{jdl} /$ art \\
\hline 2016 & 34 & 745 & $21,91 \mathrm{jdl} /$ art \\
\hline $\begin{array}{c}\text { Jumlah } \\
\text { Rata- } \\
\text { rata/tah } \\
\text { un }\end{array}$ & 241 & 5.178 & 100 \\
\hline
\end{tabular}

Referensi yang digunakan artikel pada 2011 sampai dengan 2016 berturut-turut adalah 20,64 judul/artikel; 20,61 judul/artikel; 21,17 judul/artikel; 21,17 judul/artikel; 22,91 judul/artikel dan 21,91 judul/artikel. Secara rata-rata referensi yang digunakan selama 20112016 adalah 21,48 judul/artikel.

Kondisi ini sesuai dengan jumlah artikel yang semakin menurun setiap tahunnya, dengan demikian jumlah referensi yang digunakan juga menurun.

\section{c. Jumlah dan Jenis Kelamin Penulis Berita Biologi 2011-2016}

Data jumlah dan jenis kelamin penulis setelah dilakukan pengolahan selanjutnya disajikan dalam Tabel 4.

Tabel 4. Jumlah dan jenis kelamin penulis Berita Biologi 2011-2016

\begin{tabular}{|c|c|c|c|}
\hline Tahun & Laki-laki & Perempuan & Jumlah \\
\hline 2011 & $\begin{array}{c}79 \\
(12,92 \%)\end{array}$ & $47(7,69 \%)$ & $\begin{array}{c}126 \\
(20,62 \%)\end{array}$ \\
\hline 2012 & $49(8,02 \%)$ & $55(9,00 \%)$ & $\begin{array}{c}104 \\
(17,02 \%)\end{array}$ \\
\hline 2013 & $50(8,18 \%)$ & $48(7,85 \%)$ & $\begin{array}{c}98 \\
(16,04 \%)\end{array}$ \\
\hline 2014 & $52(8,51 \%)$ & $43(7,03 \%)$ & $\begin{array}{c}95 \\
(15,55 \%)\end{array}$ \\
\hline 2015 & $39(6,38 \%)$ & $48(7,85 \%)$ & $\begin{array}{c}87 \\
(14,24 \%)\end{array}$ \\
\hline 2016 & $50(8,18 \%)$ & $51(8,35 \%)$ & $\begin{array}{c}101 \\
(16,53 \%)\end{array}$ \\
\hline Jumlah & 319 & $292(47,79 \%)$ & $\begin{array}{c}611(100 \\
\%)\end{array}$ \\
\hline
\end{tabular}

Berdasarkan Tabel 4 di atas dapat diketahui bahwa jumlah penulis adalah 611 orang terdiri atas 319 laki-laki (52,21\%) dan 291 perempuan (47,79\%). Jumlah penulis perempuan yang mengungguli penulis laki-laki berada pada tahun 2012 yaitu 49 laki-laki $(8,02 \%)$ dan perempuan 55 penulis $(9,00 \%)$. Berikutnya pada tahun 2015 dengan komposisi penulis perempuan sebanyak 48 orang $(7,85 \%)$ dan laki-laki 39 orang (6,38\%) dan pada tahun 2016 dengan penulis laki-laki 50 orang $(8,18 \%)$ dan perempuan 51 orang $(8,35 \%)$.

Kondisi tersebut menggambarkan bahwa penulis perempuan tidak kalah aktif jika dibandingkan penulis laki-laki walaupun secara jumlah total penulis lakilaki lebih banyak dibandingkan penulis perempuan, namun dalam kurun enam tahun penulis laki-laki sama produktifnya dengan penulis perempuan, artinya 
terdapat tiga periode yaitu 2012, 2015 dan 2016 menempatkan penulis perempuan lebih tinggi dibandingkan dari penulis laki-laki dan tiga periode yaitu 2011, 2013 dan 2014 penulis laki-laki unggul dibandingkan penulis perempuan.

\section{d. Kolaborasi Penulis Berita Biologi 2011- 2016}

Untuk mengetahui penulis yang melakukan kolaborasi serta menghitung tingkat kolaborasi digunakan rumus Subramanyam di atas dan hasilnya ditampilkan pada Tabel 5 berikut.

Tabel 5. Tingkat kolaborasi penulis Berita Biologi 2011- 2016

\begin{tabular}{|c|c|c|c|c|l|}
\hline No: & Tahun & $\begin{array}{l}\text { Artikel } \\
\text { Individ } \\
\text { u: } \\
(\mathrm{Ns})\end{array}$ & $\begin{array}{l}\text { Artikel } \\
\text { Kolabor } \\
\text { asi: } \\
(\mathrm{Nm})\end{array}$ & $\begin{array}{l}\text { Jumlah } \\
\text { artikel: } \\
(\mathrm{N})\end{array}$ & $\begin{array}{l}\text { Tingkat } \\
\text { kolaborasi } \\
=\text { Nm / } \\
(\mathrm{Nm}+\mathrm{Ns})\end{array}$ \\
\hline 1 & 2011 & 8 & 40 & 48 & $\begin{array}{l}40 /(8+48) \\
=0,71\end{array}$ \\
\hline 2 & 2012 & 11 & 33 & 44 & $\begin{array}{l}33 /(11+33 \\
)=0,75\end{array}$ \\
\hline 3 & 2013 & 11 & 34 & 45 & $\begin{array}{l}34 /(11+34 \\
)=0,75\end{array}$ \\
\hline 4 & 2014 & 10 & 28 & 38 & $\begin{array}{l}28 /(10+28 \\
)=0,73\end{array}$ \\
\hline 5 & 2015 & 7 & 25 & 32 & $\begin{array}{l}25 /(7+25) \\
=0,78\end{array}$ \\
\hline 6 & 2016 & 5 & 29 & 34 & $\begin{array}{l}29 /(5+29) \\
=0,85\end{array}$ \\
\hline & $\begin{array}{c}\text { Jumla } \\
\mathrm{h}\end{array}$ & 52 & 189 & 241 & $\begin{array}{l}189 / \\
(52+189)= \\
0,78\end{array}$ \\
\hline
\end{tabular}

Diketahui nilai tingkat kolaborasi menurut tahun berturut-turut adalah: 0,71 0,$75 ; 0,75 ; 0,73 ; 0,78 ; 0,85$, sehingga ratarata tingkat kolaborasi periode 2011-2016 adalah 0,78. Dengan demikian tingkat kolaborasi terendah terjadi pada kurun 2011 dan paling tinggi pada tahun 2015.

Secara umum hal ini menunjukkan bahwa jumlah artikel yang ditulis secara individu lebih sedikit dibandingkan dengan artikel yang ditulis secara kolaborasi yaitu pada 2011, 2012, 2013, 2014, 2015 dan 2016; atau dengan kata lain peneliti melakukan kolaborasi dengan baik dengan sesama peneliti di bidang biologi.

Jumlah artikel yang ditulis secara individu periode 2011-2016 adalah 52 judul $(21,58 \%)$ dan artikel yang ditulis secara kolaborasi sebanyak 189 judul $(78,42 \%)$.

\section{e. Produktivitas Penulis Berita Biologi 2011-2016}

Untuk mengetahui produktivitas penulis Berita Biologi periode 2011-2016 dapat dilihat dari Tabel 6 berikut. Diketahui bahwa peringkat pertama dipegang oleh Ani Susilawati dari Balai Penelitian Pertanian Lahan Rawa (BALITTRA) dengan jumlah tulisan sebanyak 5 judul (2,07\%). Disusul di tempat ke dua yaitu Kartini Kartadibarata peneliti dari Pusat Penelitian Biologi LIPI menyumbang 4 judul artikel (1,65\%). Berikutnya pada peringkat ke tiga adalah Erlin Rachman (Pusat Penelitian Biologi LIPI) Kusuma Dewi Sri Yulia (Pusat Penelitian Biologi LIPI), Puji Lestari (Balai Besar Penelitian \& Pengembangan Bioteknologi dan Sumberdaya Genetik Pertanian) dan Tri Murningsih (Pusat Penelitian Biologi LIPI) dengan jumlah artikel berjumlah 3 judul (1,24\%). Pada peringkat ke empat adalah penulis yang menulis dua judul artikel dengan jumlah 23 orang $(9,54 \%)$ dan sebanyak 166 penulis berada di posisi ke lima dengan jumlah tulisan satu judul $(68,88 \%)$

Tabel 6. Penulis vs karya tulis yang dihasilkan

\begin{tabular}{|l|c|c|c|l|}
\hline Nama penulis & $\begin{array}{c}\text { Karya } \\
\text { tulis } \\
\text { (judul) }\end{array}$ & $\%$ & Peringkat & Instansi \\
\hline $\begin{array}{l}\text { A. Gita } \\
\text { Maulidiyah }\end{array}$ & 2 & 0,83 & 4 & $\begin{array}{l}\text { Fakultas } \\
\text { MIPA }\end{array}$ \\
\hline
\end{tabular}




\begin{tabular}{|c|c|c|c|c|c|c|c|c|c|}
\hline Indrawasri & & & & $\begin{array}{l}\text { UNHAS } \\
\text { Makasssar }\end{array}$ & Sendow & & & & $\begin{array}{l}\text { Peternakan } \\
\text { Kementan }\end{array}$ \\
\hline Ali Asgar & 2 & 0,83 & 4 & $\begin{array}{l}\text { Balai } \\
\text { Penelitian } \\
\text { Tanaman } \\
\text { Sayuran }\end{array}$ & $\begin{array}{l}\text { Irin Iriana } \\
\text { Kusmini }\end{array}$ & 2 & 0,83 & 4 & $\begin{array}{l}\text { Balai } \\
\text { Budidaya } \\
\text { Mandiangi } \\
\mathrm{n}\end{array}$ \\
\hline \multirow[t]{3}{*}{ Ani Susilawati } & \multirow[t]{3}{*}{5} & \multirow[t]{3}{*}{2,07} & \multirow[t]{3}{*}{1} & \multirow{3}{*}{$\begin{array}{l}\text { Balai } \\
\text { Penelitian } \\
\text { Pertanian } \\
\text { Lahan } \\
\text { Rawa } \\
\text { (BALITTR } \\
\text { A), } \\
\text { Banjarbaru } \\
\text { Kalimantan } \\
\text { Selatan }\end{array}$} & $\begin{array}{l}\text { Iwan } \\
\text { Saskiawan }\end{array}$ & 2 & 0,83 & 4 & $\begin{array}{l}\text { Pusat } \\
\text { Penelitian } \\
\text { Biologi } \\
\text { LIPI }\end{array}$ \\
\hline & & & & & $\begin{array}{l}\text { Kartini } \\
\text { Kramadibarata }\end{array}$ & 4 & 1,65 & 2 & $\begin{array}{l}\text { Pusat } \\
\text { Penelitian } \\
\text { Biologi } \\
\text { LIPI }\end{array}$ \\
\hline & & & & & \multirow[t]{2}{*}{$\begin{array}{l}\text { Kusuma Dewi } \\
\text { Sri Yulia }\end{array}$} & \multirow[t]{2}{*}{3} & \multirow[t]{2}{*}{1,24} & \multirow[t]{2}{*}{3} & $\begin{array}{l}\text { Pusat } \\
\text { Penelitian }\end{array}$ \\
\hline \multirow[t]{2}{*}{$\begin{array}{l}\text { Ayda } \\
\text { Krisnawati }\end{array}$} & \multirow[t]{2}{*}{2} & \multirow[t]{2}{*}{0,83} & \multirow[t]{2}{*}{4} & \multirow{2}{*}{$\begin{array}{l}\text { Pusat } \\
\text { Penelitian } \\
\text { dan } \\
\text { Pengemban } \\
\text { gan } \\
\text { Tanaman } \\
\text { Pangan, } \\
\text { Balitbang } \\
\text { Pertanian } \\
\end{array}$} & & & & & $\begin{array}{l}\text { Biologi } \\
\text { LIPI }\end{array}$ \\
\hline & & & & & $\begin{array}{l}\text { Lies } \\
\text { Setijaningsih }\end{array}$ & 2 & 0,83 & 4 & $\begin{array}{l}\text { Balai } \\
\text { Penelitian } \\
\text { dan } \\
\text { Pengemban } \\
\text { gan } \\
\text { Perikanan } \\
\text { Budidaya }\end{array}$ \\
\hline \multirow{2}{*}{$\begin{array}{l}\text { Deden } \\
\text { Girmansyah }\end{array}$} & \multirow[t]{2}{*}{2} & \multirow[t]{2}{*}{0,83} & \multirow[t]{2}{*}{4} & \multirow{2}{*}{$\begin{array}{l}\text { Pusat } \\
\text { Penelitian } \\
\text { Biologi } \\
\text { LIPI }\end{array}$} & & & & & Air Tawar \\
\hline & & & & & $\begin{array}{l}\text { Muhammad } \\
\text { Mansur }\end{array}$ & 2 & 0,83 & 4 & $\begin{array}{l}\text { Pusat } \\
\text { Penelitian } \\
\text { Biologi }\end{array}$ \\
\hline \multirow{2}{*}{$\begin{array}{l}\text { Dewi } \\
\text { Wulansari }\end{array}$} & \multirow[t]{2}{*}{2} & \multirow[t]{2}{*}{0,83} & \multirow[t]{2}{*}{4} & \multirow{2}{*}{$\begin{array}{l}\text { Pusat } \\
\text { Penelitian } \\
\text { Biologi } \\
\text { LIPI }\end{array}$} & & & & & LIPI \\
\hline & & & & & $\begin{array}{l}\text { Mulyati } \\
\text { Rahayu }\end{array}$ & 2 & 0,83 & 4 & $\begin{array}{l}\text { Pusat } \\
\text { Penelitian } \\
\text { Biologi }\end{array}$ \\
\hline \multirow[t]{2}{*}{ Dian Latifah } & \multirow[t]{2}{*}{2} & \multirow[t]{2}{*}{0,83} & \multirow[t]{2}{*}{4} & \multirow{2}{*}{$\begin{array}{l}\text { PKT Kebun } \\
\text { Raya Bogor } \\
\text { LIPI }\end{array}$} & & & & & LIPI \\
\hline & & & & & \multirow[t]{3}{*}{ Puji Lestari } & \multirow[t]{3}{*}{3} & \multirow[t]{3}{*}{1,24} & 3 & $\begin{array}{l}\text { Balai Besar } \\
\text { Penelitian }\end{array}$ \\
\hline $\begin{array}{l}\text { Didik T } \\
\text { Subekti }\end{array}$ & 2 & 0,83 & 4 & $\begin{array}{l}\text { Fakultas } \\
\text { Farmasi } \\
\text { Universitas } \\
\text { Pancasila }\end{array}$ & & & & & $\begin{array}{l}\& \\
\text { Pengemban } \\
\text { ganBiotekn } \\
\text { ologi dan }\end{array}$ \\
\hline $\begin{array}{l}\text { Dwinita } \\
\text { Wikan Utami }\end{array}$ & 2 & 0,83 & 4 & $\begin{array}{l}\text { Badan } \\
\text { Litbang } \\
\text { Bioteknolo }\end{array}$ & & & & & $\begin{array}{l}\text { Sumberday } \\
\text { a Genetik } \\
\text { Pertanian }\end{array}$ \\
\hline & & 8 & W & $\begin{array}{l}\text { gi \& } \\
\text { Sumberday } \\
\text { a Genetik } \\
\text { Pertanian }\end{array}$ & $\begin{array}{l}\text { Rianta Pratiwi } \\
\text { Samsudin }\end{array}$ & 2 & 0,83 & 4 & $\begin{array}{l}\text { Pusat } \\
\text { Penelitian } \\
\text { Oseanograf } \\
\text { i }\end{array}$ \\
\hline Erlin Rachman & 3 & 1,24 & 3 & Pusat & & & & & \\
\hline & & & & $\begin{array}{l}\text { Penelitian } \\
\text { Biologi } \\
\text { LIPI }\end{array}$ & Solikin & 2 & 0,83 & 4 & $\begin{array}{l}\text { UPT Kebun } \\
\text { Raya } \\
\text { Purwodadi }\end{array}$ \\
\hline Fris Johnny & 2 & 0,83 & 4 & Balai Besar & & & & & LIPI \\
\hline & & & & $\begin{array}{l}\text { Penelitian } \\
\text { dan } \\
\text { Pengemban } \\
\text { gan }\end{array}$ & Suyadi & 2 & 0,83 & 4 & $\begin{array}{l}\text { Pusat } \\
\text { Penelitian } \\
\text { Laut Dalam } \\
\text { LIPI }\end{array}$ \\
\hline & & & & $\begin{array}{l}\text { Budidaya } \\
\text { Laut }\end{array}$ & Titi Juhaeti & 2 & 0,83 & 4 & $\begin{array}{l}\text { Pusat } \\
\text { Penelitian }\end{array}$ \\
\hline $\begin{array}{l}\text { Heddy } \\
\text { Julistiono }\end{array}$ & 2 & 0,83 & 4 & $\begin{array}{l}\text { Pusat } \\
\text { Penelitian }\end{array}$ & & & & & $\begin{array}{l}\text { Biologi } \\
\text { LIPI }\end{array}$ \\
\hline & & & & $\begin{array}{l}\text { Biologi } \\
\text { LIPI }\end{array}$ & $\begin{array}{l}\text { Tri } \\
\text { Murningsih }\end{array}$ & 3 & 1,24 & 3 & $\begin{array}{l}\text { Pusat } \\
\text { Penelitian }\end{array}$ \\
\hline Indrawati & 2 & 0,83 & 4 & Puslitbang & & & & & Biologi \\
\hline
\end{tabular}




\begin{tabular}{|l|c|c|c|l|}
\hline & & & & \\
\hline $\begin{array}{l}\text { Wahyu } \\
\text { Pamungkas }\end{array}$ & 2 & 0,83 & 4 & $\begin{array}{l}\text { LIPI } \\
\text { Penelitian } \\
\text { Pemuliaan } \\
\text { Ikan }\end{array}$ \\
\hline $\begin{array}{l}\text { Yati } \\
\text { Sudaryanti } \\
\text { Soeka }\end{array}$ & 2 & 0,83 & 4 & $\begin{array}{l}\text { Pusat } \\
\text { Penelitian } \\
\text { Biologi } \\
\text { LIPI }\end{array}$ \\
\hline $\begin{array}{l}\text { Yuyu } \\
\text { Suryasari } \\
\text { Poerba }\end{array}$ & 2 & 0,83 & 4 & $\begin{array}{l}\text { Pusat } \\
\text { Penelitian } \\
\text { Biologi } \\
\text { LIPI }\end{array}$ \\
\hline $\begin{array}{l}\text { Penulis } \\
\text { menulis 1 } \\
\text { artikel }\end{array}$ & 166 & 68,88 & 5 & \\
\hline JUMLAH & $\mathbf{2 4 1}$ & $\mathbf{1 0 0}$ & & \\
\hline
\end{tabular}

\section{KESIMPULAN}

Secara ringkas dapat disimpulkan bahwa Berita Biologi Jurnal Ilmu-ilmu Hayati periode 2011-2016 memuat 241 judul, dengan penulis laki-laki lebih banyak dibandingkan penulis perempuan, penulis berkolaborasi lebih banyak dibandingkan penulis individu, hal ini ditandai dengan nilai tingkat kolaborasi rata-rata sebesar 0,78 dan Ani Susilawati merupakan penulis produktif dengan jumlah artikel 5 judul berasal dari Balai Penelitian Pertanian Lahan Rawa (BALITTRA), Banjarbaru Kalimantan Selatan

\section{DAFTAR PUSTAKA}

Arya, C. \& Sharma, S. (2011). Authorship trends and collaborative research in veterinary sciences: A bibliometric study. Chinese Librarianship: an International Electronic Journal, 34. URL://http.www.iclc.us/cliej/cl34 AS.pdf; diakses 05 Juli 2017.

Bernard, S.M.; (2010) The first 30 years of the journal of Crustacean Biology -

A bibliometric study. Journal of Crustacean Biology, 30 (4) : 541 549.

Dhiman, A.K. (2000). Ethnobotany Journals : A ten year bibliometric study. ASLIC Bulletin 45 (4) : 177 182

Dyah, R.M.N dan Eric ,I. Z (2017) Bahasa jadi kendala peneliti go internasional. REPUBLIKA, 14 Juli; Hal. : 05; Kol. :1-5

Gordon (1980). A critical reassessment of inferred relations between multiple authorship, scientific collaboration, the production of papers and their acceptance for publication. Scientometric, 2 (3) 193 - 201.

J.S. Kaltz dan R.B.Martin. (1997) What is research collaboration? Research Policy $26: 1-18$.

Kumar, N. (1986). Literature contribution in Journal of environmental biology : A bibliometric study. Annals of Library Science and Documentation 33 (1-2), $31-40$.

K. Subramanyam (1983). Bibliometric studies of research collaboration : A riview. Journal of Information Science $6: 33-38$.

Nandi, Amitaya and Bandyopadhyay, K.B. ( 2012) Comparative research performance analyses of the Departments of botany and zoology of the University of Burdwan from 1960 - 2000. Library Philosophy and Practice . (ejournal). 742

Neelama. G et al (2016). Authorship pattern and research collaboration of journals of botany. International Journal of Library $\mathcal{E}$ Educational Science : 2 (4) : 1-10.

T. HE et al. (2005). Basic research in biochemistry and molecular biology in China: A bibliometric analysis. Scientometrics 62 (2) : 249 259.

Thanuskodi, S. (2012). Bibliometric analysis of Indian Journal of Agricultural Research. International Journal of Information Dissemination and Technology, 2(3), 170-175. 
Thavamani, Kotti. (2017) .Authorship patterns and collaborative research in the Journal of biofuels, 2010 2016. Library Philosophy and Practice (e-journal) 1518.

http://digitalcommons.unl.edu/libphilp rac/1518, diakses 05 Juli 2017.

Vimala, V and V.Pulla Reddy (1996).

Authorship pattern and

collaborative research in the field of zoology. Malaysian Journal of Library $\mathcal{E}$ Information Sience, 1 (2) : 43 - 50. 